\title{
Gulosibacter chungangensis sp. nov., an actinomycete isolated from a marine sediment, and emended description of the genus Gulosibacter
}

\author{
Correspondence \\ Wonyong Kim \\ kimwy@cau.ac.kr
}

\author{
Mi-Hak Park,† Jitsopin Traiwan,† Min Young Jung and Wonyong Kim \\ Department of Microbiology, Chung-Ang University College of Medicine, 221 Heukseok-dong \\ Dongjak-gu, Seoul 156-756, Republic of Korea
}

\begin{abstract}
A Gram-positive, strictly aerobic, non-spore-forming, irregular short rod, strain CAU $9625^{\top}$, was isolated from a sediment of the Yellow Sea in the Republic of Korea. Strain CAU $9625^{\top}$ grew optimally at $37{ }^{\circ} \mathrm{C}$, at $\mathrm{pH} 8.0$ and in the presence of $1 \%(\mathrm{w} / \mathrm{v}) \mathrm{NaCl}$. Phylogenetic analysis based on 16S rRNA gene sequences showed that strain CAU $9625^{\top}$ belonged to the genus Gulosibacter, which has one known member, Gulosibacter molinativorax. Strain CAU $9625^{\top}$ and G. molinativorax $\mathrm{ON} 4^{\top}$ shared $97.8 \% 16 \mathrm{~S}$ rRNA gene sequence similarity and formed a distinct cluster ( $99 \%$ bootstrap support) within the family Microbacteriaceae. DNA-DNA relatedness between strain CAU $9625^{\top}$ and G. molinativorax DSM $13485^{\top}$ was $35.4 \pm 0.9 \%$. The predominant menaquinone was MK-9. The major whole-cell sugars were ribose and glucose. The major polar lipids were diphosphatidylglycerol, phosphatidylglycerol, an unidentified phospholipid and an unidentified lipid. The fatty acid composition was similar to that of G. molinativorax DSM $13485^{\top}$, with anteiso- $C_{15: 0}$ as the predominant fatty acid. The DNA G $+C$ content of strain CAU $9625^{\top}$ was $66.2 \mathrm{~mol} \%$. The phylogenetic and genetic distinctiveness and several differentiating phenotypic and chemotaxonomic properties revealed that strain CAU $9625^{\top}$ was distinguishable from G. molinativorax and other phylogenetic neighbours. On the basis of these data, strain CAU $9625^{\top}$ represents a novel species of the genus Gulosibacter, for which the name Gulosibacter chungangensis sp. nov. is proposed. The type strain is CAU $9625^{\top}\left(=\mathrm{KCTC}_{13959^{\top}}=\mathrm{CCUG}\right.$ $\left.60841^{\top}\right)$.
\end{abstract}

The family Microbacteriaceae, of the suborder Micrococcineae, embraces a large group of actinomycetes with cell-wall peptidoglycan of the B-type (Schleifer \& Kandler, 1972) and unsaturated major menaquinones (Collins \& Jones, 1981). The suborder Micrococcineae was established on the basis of a characteristic set of 16S rRNA gene signature nucleotides (Stackebrandt et al., 1997; Stackebrandt \& Schumann, 2006; Zhi et al., 2009). At the time of writing, the suborder comprises 16 recognized families and 97 genera (Euzéby, 1997), including the genus Gulosibacter, which was created by Manaia et al. (2004). Phylogenetically, it constitutes a distinct evolutionary lineage, which is most closely related to the genus Pseudoclavibacter. At present, the genus Gulosibacter contains a single species with a validly published name, Gulosibacter molinativorax, which was described on the basis of a single strain isolated from a

†These authors contributed equally to this work.

Abbreviation: DAB, diaminobutyric acid.

The GenBank/EMBL/DDBJ accession number for the 16S rRNA gene sequence of strain CAU $9625^{\top}$ is HQ268603.

A supplementary figure and table are available with the online version of this paper. herbicide-contaminated mixture of soil and water. The members of this genus are Gram-positive rods and contain D-ornithine as the diagnostic diamino acid in the peptidoglycan (Manaia et al., 2004).

In the course of screening bacteria from marine samples for their biotechnological potential, a bacterium, designated strain CAU $9625^{\mathrm{T}}$, was isolated from a marine sediment near Oh Island ( $\left.33^{\circ} 29^{\prime} 31.15^{\prime \prime} \mathrm{N} 126^{\circ} 57^{\prime} 08.01^{\prime \prime} \mathrm{E}\right)$ in the Republic of Korea. The procedure for the isolation of strain CAU $9625^{\mathrm{T}}$ followed that of Gordon \& Mihm (1962) using glucose-yeast extract agar (GYE; containing $1^{-1}$ : $10 \mathrm{~g}$ yeast extract, $10 \mathrm{~g}$ glucose, $15 \mathrm{~g}$ agar; $\mathrm{pH}$ 7.0) supplemented with $50 \mathrm{mg}$ cycloheximide $1^{-1}$ and $20 \mathrm{mg}$ nalidixic acid $1^{-1}$. A sediment sample was diluted with sterilized distilled water and appropriate dilutions were spread on GYE agar and incubated under aerobic conditions at $30{ }^{\circ} \mathrm{C}$ for 3 days. The isolate was preserved at $-70{ }^{\circ} \mathrm{C}$ in GYE broth supplemented with $25 \%(\mathrm{v} / \mathrm{v})$ glycerol. The study followed the proposed minimal standards for describing new genera and species of the suborder Micrococcineae (Schumann et al., 2009).

To determine the morphological, physiological and biochemical characteristics, strain CAU $9625^{\mathrm{T}}$ was cultivated 
routinely on brain heart infusion agar (BHI; Difco) at $30{ }^{\circ} \mathrm{C}$ except for spore formation and fatty acid analysis. The Gram-staining and $\mathrm{KOH}$ lysis tests were carried out according to Gram (1884) and Cerny (1978). Growth at 4, 10-45 (at intervals of $5{ }^{\circ} \mathrm{C}$ ) and $37{ }^{\circ} \mathrm{C}$ was determined on BHI agar in an aerobic incubator (model MIR-253; Sanyo) or an anaerobic chamber (model Bactron; Sheldon) for 3 days. Growth at $\mathrm{pH} 5.0-11.0$ (at intervals of $0.5 \mathrm{pH}$ unit) was investigated at $30{ }^{\circ} \mathrm{C}$ for 3 days in $\mathrm{BHI}$ broth with the $\mathrm{pH}$ adjusted with sodium acetate/acetic acid and $\mathrm{Na}_{2} \mathrm{CO}_{3}$ buffers. Growth with $0-15 \%(w / v) ~ \mathrm{NaCl}$ (at intervals of $1 \%$ ) was investigated in $\mathrm{BHI}$ broth at $30{ }^{\circ} \mathrm{C}$ for 3 days. A nutrient sporulation medium was used to test for spore production (Nicholson \& Setlow, 1990). After 3 days at $30{ }^{\circ} \mathrm{C}$, the presence of endospores was determined using malachite green staining (Smibert \& Krieg, 1994). Catalase activity was determined by bubble production in $3 \%(\mathrm{v} / \mathrm{v})$ hydrogen peroxide. Oxidase activity was tested by means of the oxidation of $1 \%$ tetramethyl-p-phenylenediamine (Merck) as described by Cowan \& Steel (1965). Enzymic activities and acid production from carbohydrates were tested using the API $50 \mathrm{CHB}$, API ZYM and API Coryne systems (bioMérieux) according to the manufacturer's instructions, as recommended by Schumann et al. (2009).

For the determination of fatty acid composition, cell mass was harvested from tryptic soy agar (Difco) after cultivation for 3 days at $30{ }^{\circ} \mathrm{C}$. The physiological age of the harvested biomass was standardized by observing growth development during incubation and choosing the time of harvest according to a standard protocol (Sherlock Microbial Identification System; MIDI). Cellular fatty acid methyl esters were obtained as described by Minnikin et al. (1980) and separated by an automated GC system (model 6890N and 7683 autosampler; Agilent). Peaks were identified using the Microbial Identification software (version 6.1, database TSBA6). Menaquinones were analysed as described by Komagata \& Suzuki (1987) by reversed-phase HPLC. Polar lipids were extracted and analysed by two-dimensional TLC according to Minnikin et al. (1984). Whole-cell sugars were analysed by TLC according to the method of Komagata \& Suzuki (1987). Peptidoglycan analysis was performed by the identification service at the DSMZ as described by Schleifer (1985), with the modification that TLC and two-dimensional TLC were substituted for paper chromatography. The molar aminoacid ratio in the peptidoglycan was determined by GC and GC/MS according to MacKenzie (1987).

Genomic DNA of strain CAU $9625^{\mathrm{T}}$ was isolated and purified by the method of Marmur (1961). PCR amplification and sequencing of the $16 \mathrm{~S}$ rRNA gene was carried out following established procedures (Cho et al., 2010). The amplified $16 \mathrm{~S}$ rRNA gene was sequenced directly using a BigDye Terminator Cycle Sequencing kit and an automatic DNA sequencer (model 3730; Applied Biosystems). Multiple alignment of the 16S rRNA gene sequence of strain CAU $9625^{\mathrm{T}}$ with $16 \mathrm{~S}$ rRNA gene sequences from a broad selection of closely related sequences in the GenBank database and calculation of sequence similarity were performed using CLUSTAL x (Thompson et al., 1997) and the EzTaxon server (Chun et al., 2007). A phylogenetic tree was reconstructed using the neighbour-joining (Saitou \& Nei, 1987), least-squares (Fitch \& Margoliash, 1967) and maximum-likelihood (Felsenstein, 1981) algorithms included in the PHYLIP suite of programs (Felsenstein, 1989). Evolutionary distances for the neighbour-joining analysis were based on the correction of Jukes \& Cantor (1969). Tree topologies were evaluated by the bootstrap resampling method with 1000 replicates (Felsenstein, 1985) of the neighbour-joining dataset using the SEQBOOT and CONSENSE programs in the PHYLIP package. DNA-DNA relatedness between the isolate and its nearest phylogenetic neighbour was estimated using the fluorometric microplate method (Ezaki et al., 1989), as modified by Goris et al. (1998). The $\mathrm{G}+\mathrm{C}$ content of the genomic DNA was determined by HPLC with a YMC-Pack ODS-A $4.6 \times 250 \mathrm{~mm}$ column and the eluent $0.55 \mathrm{M}(\mathrm{pH} 4.0) \mathrm{NH}_{4} \mathrm{H}_{2} \mathrm{PO}_{4}$ /acetonitrile $(20: 0.5, \mathrm{v} / \mathrm{v})$, according to the method of Tamaoka \& Komagata (1984).

Colonies of strain CAU $9625^{\mathrm{T}}$ were strictly aerobic, opaque, white and circular, with a diameter of $0.3-0.5 \mathrm{~mm}$ after 1 day of cultivation at $30{ }^{\circ} \mathrm{C}$ on $\mathrm{BHI}$ agar. Cells were irregular short rods, approximately $0.5-0.7 \mu \mathrm{m}$ in width and $1.0-1.3 \mu \mathrm{m}$ in length. Growth was observed at $15-40{ }^{\circ} \mathrm{C}$ (optimum $37{ }^{\circ} \mathrm{C}$ ), at $\mathrm{pH}$ 6.0-10.0 (optimum $\mathrm{pH}$ 8.0) and with $0-5 \%(\mathrm{w} / \mathrm{v}) \mathrm{NaCl}$ (optimum $1 \% \mathrm{NaCl}$ ). Cells were catalase- and oxidase-positive. API tests provided adequate phenotypic data to differentiate the isolate from $G$. molinativorax DSM $13485^{\mathrm{T}}$ (Table 1). The isolate reduced nitrate, utilized pyrazine carboxamide as a sole nitrogen source, produced esterase (C4) and produced acid from fructose, rhamnose, sorbitol and 5-ketogluconate. The isolate did not produce gelatinase, urease, 2-naphthylphosphatase, 2-naphthyl- $\beta$-D-galactopyranosidase, alkaline phosphatase, valine arylamidase, cystine arylamidase, acid phosphatase, naphthol-AS-BI-phosphohydrolase, $\beta$-glucuronidase or $\alpha$-glucosidase. The key phenotypic characteristics of the isolate are given in the species description.

The peptidoglycan of strain CAU $9625^{\mathrm{T}}$ contained alanine, glycine, 2,4-diaminobutyric acid, ornithine and glutamic acid in the approximate molar ratio of $0.4: 1.1: 0.4$ : $0.3: 1.0$. Peptidoglycans of this type have been reported for the genera Agreia (Evtushenko et al., 2001) and Humibacter (Vaz-Moreira et al., 2008). On the basis of these data, the isolate has peptidoglycan of the B-type with a Gly-D-Glc motif like strain G. molinativorax DSM $13485^{\mathrm{T}}$ (Manaia et al., 2004). However, G. molinativorax contains only Dornithine. The peptidoglycan type of strain CAU $9625^{\mathrm{T}}$ is different from those of the closely related strains $G$. molinativorax DSM $13485^{\mathrm{T}}$, Zimmermannella bifida IAM $14848^{\mathrm{T}}$, Zimmermannella faecalis NBRC $15706^{\mathrm{T}}$, Pseudoclavibacter chungangensis KCTC $22691^{\mathrm{T}}$, Pseudoclavibacter helvolus DSM $20419^{\mathrm{T}}$ and Pseudoclavibacter soli $\mathrm{KP}^{2} 2^{\mathrm{T}}$, which contain D-ornithine, L-diaminobutyric acid (L-DAB), Hsr and L-DAB, DAB, DAB, and DAB, 
Table 1. Differential phenotypic properties of strain CAU $9625^{\top}$ and the type strains of closely related taxa of the family Microbacteriaceae

Strains: 1 , Gulosibacter chungangensis sp. nov. CAU $9625^{\mathrm{T}} ; 2$, G. molinativorax DSM $13485^{\mathrm{T}}$; 3, Zimmermannella bifida IAM 14848 ${ }^{\mathrm{T}}$; 4, Z. faecalis NBRC $15706^{\mathrm{T}} ; 5$, Pseudoclavibacter chungangensis KCTC $22691^{\mathrm{T}} ; 6$, P. helvolus DSM $20419^{\mathrm{T}} ; 7$, P. soli KP02 ${ }^{\mathrm{T}}$. Data were taken from this study. + , Positive; $\mathrm{w}$, weakly positive; -, negative.

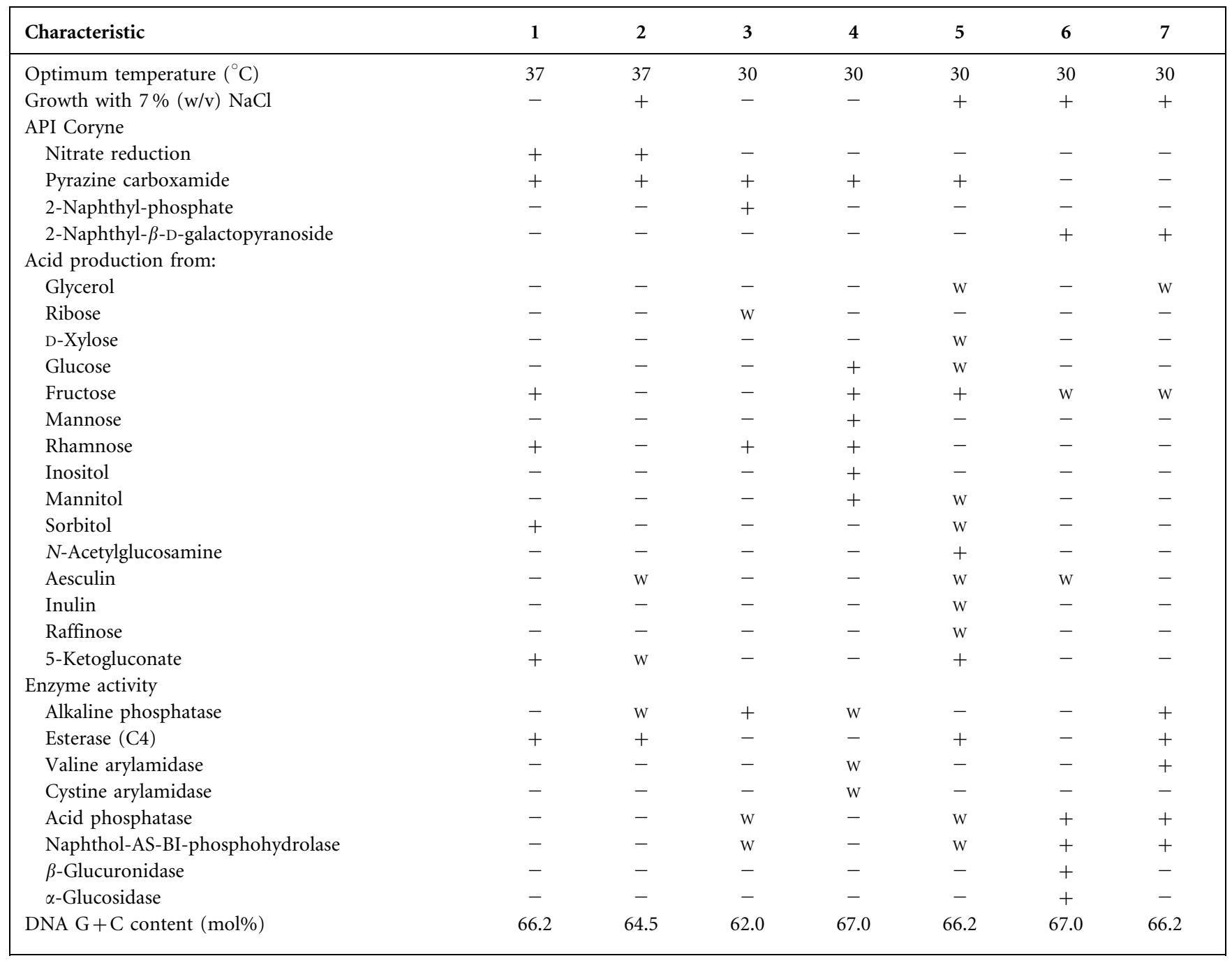

respectively (Table 2). Whole-cell hydrolysates of strain CAU $9625^{\mathrm{T}}$ contained mainly glucose and ribose, similarly to G. molinativorax. The predominant isoprenoid quinone was an unsaturated menaquinone, MK-9. The major polar lipids were diphosphatidylglycerol, phosphatidylglycerol, an unidentified phospholipid and an unidentified lipid (Fig. S1, available in IJSEM Online). Strain CAU $9625^{\mathrm{T}}$ did not contain the unidentified glycolipid reported for $G$. molinativorax (Manaia et al., 2004). The cellular fatty acids were anteiso- $\mathrm{C}_{15: 0}(48.6 \%)$, iso- $\mathrm{C}_{16: 0}(25.2 \%)$, anteiso$\mathrm{C}_{17: 0}(12.5 \%)$, iso- $\mathrm{C}_{15: 0}(7.5 \%), \mathrm{C}_{16: 0}(3.1 \%)$, iso- $\mathrm{C}_{14: 0}$ $(1.4 \%)$ and iso- $\mathrm{C}_{17: 0}(1.3 \%)$ (Table $\left.\mathrm{S} 1\right)$.

A nearly complete $16 \mathrm{~S}$ rRNA gene sequence of strain CAU $9625^{\mathrm{T}}$ (1451 bp) was determined. Phylogenetic analysis indicated that the isolate fell into a cluster comprising species of the genera Gulosibacter, Zimmermannella and
Pseudoclavibacter, but was clearly separated from the genera Pseudoclavibacter and Zimmermannella. The phylogenetic tree is shown in Fig. 1. Pairwise 16S rRNA gene sequence similarities between strain CAU $9625^{\mathrm{T}}$ and closely related strains were $97.8 \%$ (G. molinativorax $\mathrm{ON} 4^{\mathrm{T}}$ ), $96.7 \%$ (Z. bifida IAM $14848^{\mathrm{T}}$ ), $95.8 \%$ (Z. faecalis IFO $\left.15706^{\mathrm{T}}\right)$, $94.5 \%\left(P\right.$. chungangensis CAU $\left.59^{\mathrm{T}}\right), 94.6 \%(P$. helvolus DSM $20419^{\mathrm{T}}$ ), $94.4 \%$ (Z. alba IFO $15616^{\mathrm{T}}$ ) and $92.3 \%$ (P. soli $\mathrm{KP}^{\mathrm{T}} 2^{\mathrm{T}}$ ). Mean DNA-DNA relatedness between strain CAU $9625^{\mathrm{T}}$ and G. molinativorax DSM $13485^{\mathrm{T}}$ was $35.4 \pm 0.9 \%$. This value is well below the $70 \%$ cut-off point recommended by Wayne et al. (1987) for the delineation of genomic species and supports the proposal that strain CAU $9625^{\mathrm{T}}$ represents a separate species. The $\mathrm{G}+\mathrm{C}$ content of the genomic DNA of strain CAU $9625^{\mathrm{T}}$ was $66.2 \mathrm{~mol} \%$. 
Table 2. Differential chemotaxonomic properties of strain CAU $9625^{\top}$ and the type strains of closely related taxa of the family Microbacteriaceae

Strains: 1, Gulosibacter chungangensis sp. nov. CAU 9625 ${ }^{\mathrm{T}}$; 2, G. molinativorax DSM $13485^{\mathrm{T}}$ (Manaia et al., 2004); 3, Zimmermannella bifida IAM $14848^{\mathrm{T}}$ (Lin et al., 2004); 4, Z. faecalis NBRC $15706^{\mathrm{T}}$ (Lin et al., 2004); 5, Pseudoclavibacter chungangensis KCTC 22691 ${ }^{\mathrm{T}}$ (Cho et al., 2010); 6 , $P$. helvolus DSM $20419^{\mathrm{T}}$ (Lin et al., 2004); 7, P. soli KP02 ${ }^{\mathrm{T}}$ (Kim et al., 2009). ND, no data available.

\begin{tabular}{|lccccccc|}
\hline Characteristic & 1 & $\mathbf{2}$ & $\mathbf{3}$ & $\mathbf{4}$ & $\mathbf{5}$ & $\mathbf{6}$ & $\mathbf{7}$ \\
\hline Quinones & MK-9 & MK-9 & MK-8, -9 & MK-9 & MK-9 & MK-9 & MK-9, -8 \\
Polar lipids & DPG, PG, PL, L & DPG, PG, GL & ND & ND & ND & DPG, PG, GL & ND \\
Cell wall sugars $\dagger$ & Rib, Glc & Rib, Glc & Rha, Glc & Rha & Fuc & Xyl, Gal & Xyl \\
Peptidoglycan components & D-Orn, DAB & D-Orn & L-DAB & Hsr, L-DAB & DAB & DAB & DAB \\
& & & & &
\end{tabular}

${ }^{\star}$ DPG, Diphosphatidylglycerol; GL, unidentified glycolipid; PG, phosphatidylglycerol; PL, unidentified phospholipid; L, unidentified lipid. $\dagger$ Data from this study. Fuc, fucose; Gal, galactose; Glc, glucose; Rha, rhamnose; Rib, ribose; Xyl, xylose.

The phenotypic and chemotaxonomic data, together with the results of the $16 \mathrm{~S}$ rRNA gene phylogenetic analysis and DNA-DNA relatedness study, support the proposal that strain CAU $9625^{\mathrm{T}}$ represents a novel species within the genus Gulosibacter, for which the name Gulosibacter chungangensis sp. nov. is proposed.

\section{Emended description of the genus Gulosibacter}

Gulosibacter (Gu.lo'si.bac.ter. L. adj. gulosus fond of titbits, dainty feeder; N.L. masc. n. bacter rod; N.L. masc. n. Gulosibacter rod fond of titbits).

The description of the genus Gulosibacter is as given by Manaia et al. (2004) with the following amendments. The peptidoglycan is based on ornithine or ornithine and 2,4diaminobutyric acid. The characteristic polar lipids are diphosphatidylglycerol and phosphatidylglycerol. Wholecell hydrolysates contain mainly glucose and ribose. The $\mathrm{G}+\mathrm{C}$ content is $64.5-66.2 \mathrm{~mol} \%$.

\section{Description of Gulosibacter chungangensis sp. nov.}

Gulosibacter chungangensis (chung.ang.en'sis. N.L. masc. adj. chungangensis named after Chung-Ang University, where the taxonomic studies on this species were performed).

Colonies are strictly aerobic, opaque, white and circular, with a diameter of $0.3-0.5 \mathrm{~mm}$ after 1 day of cultivation at $30{ }^{\circ} \mathrm{C}$ on $\mathrm{BHI}$ agar. Cells are irregular short rods, approximately $0.5-0.7 \mu \mathrm{m}$ in width and $1.0-1.3 \mu \mathrm{m}$ in length. Growth occurs at $15-40{ }^{\circ} \mathrm{C}$ (optimum $37{ }^{\circ} \mathrm{C}$ ), at $\mathrm{pH} 6.0-10.0$ (optimum $\mathrm{pH} 8.0$ ) and with $0-5 \%(\mathrm{w} / \mathrm{v})$ $\mathrm{NaCl}$ (optimum $1 \% \mathrm{NaCl}$ ). Cells are catalase- and oxidasepositive. Nitrate is reduced and pyrazine carboxamide is utilized as a sole nitrogen source. Positive for esterase (C4). The peptidoglycan contains ornithine in combination with 2,4-diaminobutyric acid. Acid is produced from fructose, rhamnose, sorbitol and 5-ketogluconate. The major isoprenoid quinone is MK-9. Whole-cell hydrolysates

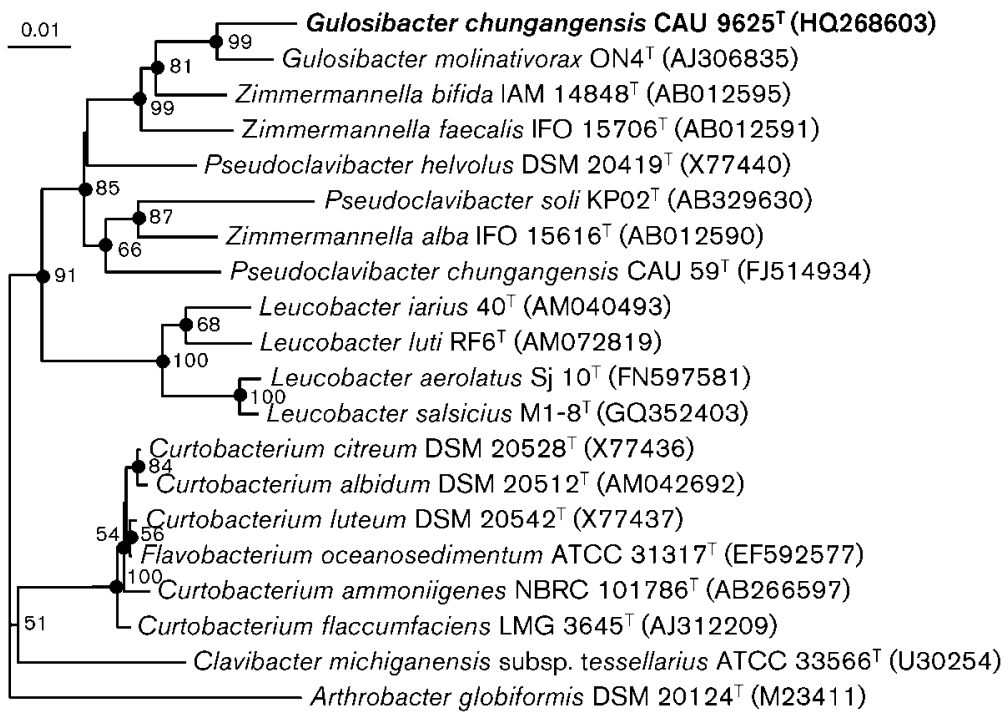

Fig. 1. Neighbour-joining phylogenetic tree based on 16S rRNA gene sequences (1451 bp) showing the relationships between strain CAU $9625^{\top}$ and the type strains of closely related taxa of the family Microbacteriaceae. Bootstrap values ( $>50 \%$ ) based on 1000 resampled datasets are shown at branch nodes. Filled circles indicate that the corresponding nodes were also recovered in trees generated with the maximum-likelihood and least-squares algorithms. Arthrobacter globiformis DSM $20124^{\top}$ was used as an outgroup. Bar, 0.01 substitutions per nucleotide position. 
contain mainly ribose and glucose. The major polar lipids are diphosphatidylglycerol, phosphatidylglycerol, an unidentified phospholipid and an unidentified lipid. The predominant cellular fatty acids are anteiso- $\mathrm{C}_{15: 0}$, iso$\mathrm{C}_{16: 0}$ and anteiso- $\mathrm{C}_{17: 0}$. The DNA G+C content of the type strain is $66.2 \mathrm{~mol} \%$.

The type strain is CAU $9625^{\mathrm{T}}\left(=\mathrm{KCTC} 13959^{\mathrm{T}}=\mathrm{CCUG}\right.$ $\left.60841^{\mathrm{T}}\right)$, which was isolated from a marine sediment near Oh Island in the Yellow Sea, Republic of Korea.

\section{Acknowledgements}

This research was supported by the Chung-Ang University research grants in 2010 .

\section{References}

Cerny, G. (1978). Studies on aminopeptidase for the distinction of Gram-negative from Gram-positive bacteria. Eur J Appl Microbiol Biotechnol 5, 113-122.

Cho, S.-L., Jung, M. Y., Park, M.-H., Chang, Y.-H., Yoon, J.-H., Myung, S. C. \& Kim, W. (2010). Pseudoclavibacter chungangensis sp. nov., isolated from activated sludge. Int J Syst Evol Microbiol 60, 1672-1677.

Chun, J., Lee, J.-H., Jung, Y., Kim, M., Kim, S., Kim, B. K. \& Lim, Y.-W. (2007). EzTaxon: a web-based tool for the identification of prokaryotes based on $16 \mathrm{~S}$ ribosomal RNA gene sequences. Int J Syst Evol Microbiol 57, 2259-2261.

Collins, M. D. \& Jones, D. (1981). Distribution of isoprenoid quinone structural types in bacteria and their taxonomic implication. Microbiol Rev 45, 316-354.

Cowan, S. T. \& Steel, K. J. (1965). Manual for the Identification of Medical Bacteria. London: Cambridge University Press.

Euzéby, J. P. (1997). List of bacterial names with standing in nomenclature: a folder available on the Internet. Int J Syst Bacteriol 47, 590-592.

Evtushenko, L. I., Dorofeeva, L. V., Dobrovolskaya, T. G., Streshinskaya, G. M., Subbotin, S. A. \& Tiedje, J. M. (2001). Agreia bicolorata gen. nov., sp. nov., to accommodate actinobacteria isolated from narrow reed grass infected by the nematode Heteroanguina graminophila. Int J Syst Evol Microbiol 51, 2073-2079.

Ezaki, T., Hashimoto, Y. \& Yabuuchi, E. (1989). Fluorometric deoxyribonucleic acid-deoxyribonucleic acid hybridization in microdilution wells as an alternative to membrane filter hybridization in which radioisotopes are used to determine genetic relatedness among bacterial strains. Int J Syst Bacteriol 39, 224-229.

Felsenstein, J. (1981). Evolutionary trees from DNA sequences: a maximum likelihood approach. J Mol Evol 17, 368-376.

Felsenstein, J. (1985). Confidence limits on phylogenies: an approach using the bootstrap. Evolution 39, 783-791.

Felsenstein, J. (1989). PHYLIP - phylogeny inference package (version 3.2). Cladistics 5, 164-166.

Fitch, W. M. \& Margoliash, E. (1967). Construction of phylogenetic trees. Science 155, 279-284.

Gordon, R. E. \& Mihm, J. M. (1962). Identification of Nocardiacaviae (Erikson) nov. comb. Ann N Y Acad Sci 98, 628-636.

Goris, J., Suzuki, K., De Vos, P., Nakase, T. \& Kersters, K. (1998). Evaluation of a microplate DNA-DNA hybridization method compared with the initial renaturation method. Can J Microbiol 44, $1148-1153$.
Gram, H. C. (1884). Über die isolierte Färbung der Schizomyceten in Schnitt-und Trockenpräparaten. Fortschr Med 2, 185-189.

Jukes, T. H. \& Cantor, C. R. (1969). Evolution of protein molecules. In Mammalian Protein Metabolism, vol. 3, pp. 21-132. Edited by H. N. Munro. New York: Academic Press.

Kim, M. K. \& Jung, H.-Y. (2009). Pseudoclavibacter soli sp. nov., a $\beta$ glucosidase-producing bacterium. Int J Syst Evol Microbiol 59, 835838 .

Komagata, K. \& Suzuki, K. (1987). Lipid and cell-wall analysis in bacterial systematics. Methods Microbiol 19, 161-207.

Lin, Y.-C., Uemori, K., de Briel, D. A., Arunpairojana, V. \& Yokota, A. (2004). Zimmermannella helvola gen. nov., sp. nov., Zimmermannella alba sp. nov., Zimmermannella bifida sp. nov., Zimmermannella faecalis sp. nov. and Leucobacter albus sp. nov., novel members of the family Microbacteriaceae. Int J Syst Evol Microbiol 54, 1669-1676.

MacKenzie, S. L. (1987). Gas chromatographic analysis of amino acids as the $N$-heptafluorobutyryl isobutyl esters. J Assoc Off Anal Chem 70, 151-160.

Manaia, C. M., Nogales, B., Weiss, N. \& Nunes, O. C. (2004). Gulosibacter molinativorax gen. nov., sp. nov., a molinate-degrading bacterium, and classification of 'Brevibacterium helvolum' DSM 20419 as Pseudoclavibacter helvolus gen. nov., sp. nov. Int J Syst Evol Microbiol 54, 783-789.

Marmur, J. (1961). A procedure for the isolation of deoxyribonucleic acid from microorganisms. J Mol Biol 3, 208-218.

Minnikin, D. E., Hutchinson, I. G., Caldicott, A. B. \& Goodfellow, M. (1980). Thin-layer chromatography of methanolysates of mycolic acid-containing bacteria. J Chromatogr A 188, 221-233.

Minnikin, D. E., O'Donnell, A. G., Goodfellow, M., Alderson, G., Athalye, M., Schaal, A. \& Paelett, J. H. (1984). An integrated procedure for the extraction of bacterial isoprenoid quinones and polar lipids. J Microbiol Methods 2, 233-241.

Nicholson, W. L. \& Setlow, P. (1990). Sporulation, germination, and outgrowth. In Molecular Biological Methods for Bacillus, pp. 391-450. Edited by C. R. Harwood \& S. M. Cutting. Sussex, UK: Wiley.

Saitou, N. \& Nei, M. (1987). The neighbor-joining method: a new method for reconstructing phylogenetic trees. Mol Biol Evol 4, 406425.

Schleifer, K. H. (1985). Analysis of the chemical composition and primary structure of murein. Methods Microbiol 18, 123-156.

Schleifer, K. H. \& Kandler, O. (1972). Peptidoglycan types of bacterial cell walls and their taxonomic implications. Bacteriol Rev 36, 407477.

Schumann, P., Kämpfer, P., Busse, H.-J., Evtushenko, L. I. \& Subcommittee on the Taxonomy of the Suborder Micrococcineae of the International Committee on Systematics of Prokaryotes. (2009). Proposed minimal standards for describing new genera and species of the suborder Micrococcineae. Int J Syst Evol Microbiol 59, 1823-1849.

Smibert, R. M. \& Krieg, N. R. (1994). Phenotypic characterization. In Methods for General and Molecular Bacteriology, pp. 607-654. Edited by P. Gerhardt, R. G. E. Murray, W. A. Wood \& N. R. Krieg. Washington, DC: American Society for Microbiology.

Stackebrandt, E. \& Schumann, P. (2006). Introduction to the taxonomy of actinobacteria. In The Prokaryotes. A Handbook on the Biology of Bacteria, 3rd edn, vol. 3, pp. 297-321. Edited by M. Dworkin, S. Falkow, E. Rosenberg, K. H. Schleifer \& E. Stackebrandt. New York: Springer-Verlag.

Stackebrandt, E., Rainey, F. \& Ward-Rainey, N. (1997). Proposal for a new hierarchic classification system, Actinobacteria classis nov. Int $J$ Syst Bacteriol 47, 479-491. 
Tamaoka, J. \& Komagata, K. (1984). Determination of DNA base composition by reverse-phase high-performance liquid chromatography. FEMS Microbiol Lett 25, 125-128.

Thompson, J. D., Gibson, T. J., Plewniak, F., Jeanmougin, F. \& Higgins, D. G. (1997). The CLUSTAL_X windows interface: flexible strategies for multiple sequence alignment aided by quality analysis tools. Nucleic Acids Res 25, 4876-4882.

Vaz-Moreira, I., Nobre, M. F., Ferreira, A. C., Schumann, P., Nunes, O. C. \& Manaia, C. M. (2008). Humibacter albus gen. nov., sp. nov., isolated from sewage sludge compost. Int J Syst Evol Microbiol 58, 1014-1018.
Wayne, L. G., Brenner, D. J., Colwell, R. R., Grimont, P. A. D., Kandler, O., Krichevsky, M. I., Moore, L. H., Moore, W. E. C., Murray, R. G. E. \& other authors. (1987). International Committee on Systematic Bacteriology. Report of the ad hoc committee on reconciliation of approaches to bacterial systematics. Int J Syst Bacteriol 37, 463464.

Zhi, X.-Y., Li, W.-J. \& Stackebrandt, E. (2009). An update of the structure and 16S rRNA gene sequence-based definition of higher ranks of the class Actinobacteria, with the proposal of two new suborders and four new families and emended descriptions of the existing higher taxa. Int J Syst Evol Microbiol 59, 589-608. 